\title{
Do patients with heart failure and preserved, mid-range or reduced ejection fraction have different outcomes?
}

\author{
Ralitsa Panchevaa, Svetoslav Yovev ${ }^{b}, V^{a}$ asil Koleva, Blagovest Stoimenov ${ }^{a}$ \\ a Cardiology Clinic, Department of Internal Diseases "Kirkovich", University Hospital Alexandrovska, Sofia, Bulgaria \\ ${ }^{b}$ Department of Electrocardiostimulation and Electrocardiophysiology, University Hospital Saint Ekaterina, Sofia, Bulgaria
}

\section{ARTICLE INFO}

Article history:

Submitted: 25. 6. 2020

Revised: 21. 9. 2020

Accepted: 9. 10. 2020

Available online: 30.11 .2020

Klíčová slova:

Ejekční frakce ve středním pásmu

Mortalita

Opakované hospitalizace

Srdeční selhání
SOUHRN

Kontext: Terminologie používaná v souvislosti se srdečním selháním (heart failure, HF) je podle doporučených postupů Evropské kardiologické společnosti z roku 2016 (2016 European Society of Cardiology Guidelines) založena na naměřených hodnotách ejekční frakce levé komory srdeční (EF LK) s následující klasifikací: $\geq 50 \%$, HF se zachovanou ejekční frakcí (HF with preserved EF, HFpEF), < $40 \%$, HF se sniženou ejekční frakcí (HF with reduced EF, HFrEF) a 40-49 \%, HF s ejekční frakcí ve středním pásmu (HF with mid-range EF, HFmrEF). Prognóza pacientů s HFpEF a HFmrEF se zatím stanovuje poměrně obtížně.

Cíl: Cílem tohoto článku je popsat etiologii, rizikové faktory, klinické a echokardiografické charakteristiky a prognózu pacientů s HFpEF, HFmrEF a HFrEF v Bulharsku.

Metody: $V$ naší observační studii byly všechny údaje pacientů získány z naší nemocniční databáze. Ve studii se hodnotily údaje 890 pacientů prijiatých na kliniku kardiologie v období 2012 až 2014 pro dekompenzované chronické srdeční selhání.

Výsledky: Parametry sledovanými u hodnocených skupin pacientů s $\operatorname{HFpEF}(609 ; 68,4$ \%), $\operatorname{HFmrEF}(145 ; 16,3 \%)$ a $\operatorname{HFrEF}(136 ; 15,3 \%)$ byly mortalita z jakýchkoli př́čin a rehospitalizace. Během sledování v délce 5,8 $\pm 1,5$ roku dosáhla mortalita hodnot $34,6 \%$ v prípadě HFpEF, 55,9 \% u HFmrEF a 61,8 \% u pacientů s HFrEF. Po adjustaci byla mortalita významně vyšší u HFrEF a HFmrEF oproti HFpEF (HR 3,67; $95 \% \mathrm{Cl} 1,74-5,56 ; p<0,01$ v př́ípadě HFrEF a HR 2,96; $95 \% \mathrm{Cl} 1,48-4,76 ; p<0,01$ u HFmrEF). Podle našich údajů došlo po druhém roce sledování u pacientů s HFrEF ke statisticky nevýznamnému zkrácení přežití ve srovnání s pacienty s HFmrEF ( $\mathrm{HR} 1,72 ; 95 \% \mathrm{Cl} 1,49-2,48 ; p=0,12$ ). V období s mediánem 1,2 roku bylo znovu hospitalizováno 22,3\% pacientů s HFpEF, 33,1 \% s HFmrEF a 33,7 \% pacientů s HFrEF. U pacientů s HFrEF i HFmrEF bylo zjištěno významně vyšší riziko opakovaného příjmu pro dekompenzované HF než u pacientů s HFpEF (HR 1,67; $95 \%$ Cl 1,20-2,35; $p<0,01$ u HFrEF, a HR 1,58; $95 \%$ Cl 1,12-2,22; $p<0,01$ u HFmrEF). Riziko rehospitalizace bylo u pacientů s HFrEF a HFmrEF podobné (HR 1,03; $95 \%$ Cl 0,93-1,08; $p=0,65)$. Analýza ROC určila jako mezní hodnotu EF $50 \%$, protože EF LK < $50 \%$ byla spojena s vyšší mortalitou i vyššími počty opakovaných hospitalizací u všech hodnocených skupin jedinců s HF (AUC 0,67; senzitivita $65 \%$; specificita $72 \%$; $p<0,01$ ). Závěr: Naše údaje prokázaly přiznivější prognózu pacientů s HFpEF než u pacientů s HFmrEF a HFrEF. Hodnoty úmrtí a opakovaných hospitalizací byly nicméně u pacientů s $\mathrm{HF}<50 \%$ podobné; to znamená, že HFmrEF může představovat časné stadium HFrEF a pro pacienty s HFmrEF mohou být přínosné stejné strategie léčby jako u pacientů s HFrEF.

(c) 2020, ČKS. 
Keywords:

Heart failure

Mid-range ejection fraction

Mortality

Rehospitalizations and $33.1 \%$, respectively) in comparison to HFpEF patients (22.3\%). The risk of rehospitalizations was similar for HFrEF and HFmrEF. The ROC-analysis showed that LVEF $<50 \%$ was associated with higher mortality and rehospitalization rates among all studied HF patients.

Conclusion: Our HFpEF patients had better prognosis than those with HFmrEF and HFrEF. The mortality and rehospitalization rates were similar in $\mathrm{HF}$ patients with $\mathrm{EF}$ below $50 \%$. HFmrEF may represent an early stage of HFrEF and HFmrEF patients may benefit from the same therapies used for HFrEF.

\section{Background}

The European Society of Cardiology (ESC) Guidelines categorize patients with heart failure (HF) by left ventricular ejection fraction (LVEF) to either preserved EF ( $\geq 50 \%$, HFpEF), mid-range EF (40-49\%, HFmrEF), or reduced EF $(<40 \%, \mathrm{HFrEF})$ with the efficacy of evidence-based therapies varying by EF grouping. ${ }^{1}$ As the population continues to age, a thorough understanding of clinical characteristics, risk factors, comorbidities and predictors of long-term outcomes of patients with different types HF will be a crucial step in the investigation and development of strategies to reduce the burden of HF morbidity and mortality. ${ }^{2-7}$

The attention on HFpEF has increased in the years, with more studies and larger trials being focused on this group of patients, but there is still no effective evidence-based therapy. ${ }^{8-10}$

Patients with HFpEF represent approximately $50 \%$ of all hospital admissions for HF. Although some studies have suggested that HFpEF patients have a substantially better prognosis compared to those with HFrEF, others have suggested that the mortality and hospitalization rates are similar. ${ }^{11-17}$

$\mathrm{HFmrEF}$ is defined as "grey" area because this group has been poorly characterized and the data on the prognosis of this type of patients are scarce. ${ }^{18-26}$ The most therapeutic evidence has been accumulated in group with HFrEF only, including effective pharmacological and device therapies that have led to significant improvements in survival. ${ }^{1}$

\section{Aim}

Our manuscript aims to investigate the etiology, risk factors, clinical and echocardiographic characteristics and prognosis of Bulgarian patients with HFpEF, HFmrEF and HFrEF.

\section{Materials and methods}

We performed an observational study. All patients' data were obtained from our Cardiology department database. The study population included 886 patients admitted to our department between the years 2012 and 2014 for decompensated chronic HF. The HF patients were stratified by EF into one of three groups: HFrEF, HFmrEF, and HFpEF based on the 2016 ESC Guidelines for diagnosis and treatment of acute and chronic HF. ${ }^{1}$ We compared the main characteristics of these three groups, such as demographics, etiology of HF, comorbidities, laboratory data, treatment (including medications), and echocardiographic parameters. The collected data of all subjects were analyzed from the moment of their first visit at our department, regardless of the time of HF diagnosis.

Complete echocardiographic investigation (including left ventricular dimensions and ejection fraction, left atrial dimensions, pulmonary artery systolic pressure) was obtained by experienced sonographer. The echocardiographic equipment Phillips iE33 was used for all measurements. LV images in each systolic and diastolic phase were acquired and recorded as four-chamber and two-chamber images from the transapical view. LVEF was calculated according to the modified Simpson method, with manual tracing of the LV endocardial border.

\section{Definition of comorbidities}

Arterial hypertension (HTN) was defined by systolic blood pressure $>140 \mathrm{mmHg}$ or diastolic blood pressure $>90$ $\mathrm{mmHg}$, physician-documented history of HTN, or current use of antihypertensive medications according to the Guidelines recommendations. ${ }^{27}$ Diabetes mellitus (DM) was defined by the presence of physician-documented history of DM or the use of oral hypoglycemic agents or insulin for the treatment of hyperglycemia. The valvular heart diseases (VHD, mitral or aortic) were assessed according to the Guidelines recommendations. ${ }^{28}$ Coronary artery disease (CAD) was defined by the presence of physician-documented history of CAD, known coronary stenosis $>50 \%$, history of myocardial infarction (MI), percutaneous intervention or coronary artery bypass grafting. Chronic kidney disease (CKD) was divided into the stages according to National Kidney Foundation (NKF). ${ }^{29}$

Informed consent forms were signed by all patients prior to their enrolment and an approval of the study was obtained from the local Ethics Committee, ethical code number $244 \mathrm{~A} / 20.09$.2017. The investigation was performed in accordance with the ethical standards as laid down in the 1964 Declaration of Helsinki and its later amendments.

\section{Statistical analysis}

Statistical analyses were performed using the SPSS version 22.0. Continuous variables were expressed as mean values \pm standard deviation and the normality of their distribution was assessed by Shapiro-Wilk test. Categorical variables were presented as percentages and compared by Chi-square tests. Kaplan0l'Meier survival curves were constructed for mortality and log-rank tests were used to compare the survival curves of the three groups. Cox proportional hazard regression analysis was performed to assess the probability of re-hospitalizations in the studied HF groups. The results were considered to be statistically significant at $p$-value $<0.05$. 
Table 1 - Clinical characteristics of patients with HF stratified by the ejection fraction

\begin{tabular}{|c|c|c|c|c|}
\hline & $\begin{array}{l}\text { HFpEF } \\
\text { n (\%) }\end{array}$ & $\begin{array}{l}\text { HFmrEF } \\
\mathrm{n}(\%)\end{array}$ & $\begin{array}{l}\text { HFrEF } \\
n(\%)\end{array}$ & $p$-value \\
\hline Age (years) & $67.3 \pm 11.3$ & $68.2 \pm 11.7$ & $68.6 \pm 10.6$ & 0.160 \\
\hline Female & $341(56.0 \%)$ & $57(39.3 \%)$ & $55(40.4 \%)$ & $<0.001$ \\
\hline Arterial hypertension (HTN) & $586(96.2 \%)$ & $130(89.7 \%)$ & $121(88.9 \%)$ & $<0.01$ \\
\hline Diabetes mellitus (DM) type 2 & $141(23.2 \%)$ & $51(35.2 \%)$ & $47(34.6 \%)$ & $<0.05$ \\
\hline Valvular heart disease (VHD) & $162(26.6 \%)$ & $58(40.0 \%)$ & $54(39.7 \%)$ & $<0.01$ \\
\hline Coronary artery disease (CAD) & $256(42.1 \%)$ & $76(52.4 \%)$ & $81(59.6 \%)$ & $<0.001$ \\
\hline Carotid vascular disease & $115(18.8 \%)$ & $20(13.8 \%)$ & $21(15.4 \%)$ & 0.256 \\
\hline Peripheral artery disease (PAD) & $86(9.19 \%)$ & $17(11.7 \%)$ & $25(18.4 \%)$ & $<0.05$ \\
\hline Cerebrovascular disease (CVD) & $111(18.2 \%)$ & $28(19.3 \%)$ & $25(18.4 \%)$ & 0.634 \\
\hline Atrial fibrillation (AF) & $337(55.3 \%)$ & $102(70.3 \%)$ & $91(66.9 \%)$ & $<0.001$ \\
\hline Thyroid gland diseases & $103(16.9 \%)$ & $18(12.4 \%)$ & $18(12.4 \%)$ & 0.388 \\
\hline Chronic obstructive pulmonary disease (COPD) & $104(17.1 \%)$ & $25(17.5 \%)$ & $24(17.6 \%)$ & 0.857 \\
\hline Anemia & $221(36.3 \%)$ & $47(32.4 \%)$ & $55(41.2 \%)$ & $<0.001$ \\
\hline GFR $\left(\mathrm{ml} / \mathrm{min} / 1.73 \mathrm{~m}^{2}\right)$ & $75.8 \pm 25.8$ & $75.2 \pm 27.9$ & $66.2 \pm 29.9$ & $<0.001$ \\
\hline
\end{tabular}

GFR - glomerular filtration rate.

\begin{tabular}{|c|c|c|c|c|}
\hline & $\begin{array}{l}\text { HFpEF } \\
\text { mean } \pm \text { SD }\end{array}$ & $\begin{array}{l}\text { HFmrEF } \\
\text { mean } \pm \text { SD }\end{array}$ & $\begin{array}{l}\text { HFpEF } \\
\text { mean } \pm \text { SD }\end{array}$ & $p$-value \\
\hline $\mathrm{EF}(\%)$ & $62.2 \pm 6.2$ & $45.7 \pm 3.2$ & $32.4 \pm 5.3$ & $<0.001$ \\
\hline LA parasternal diameter $(\mathrm{mm})$ & $45.3 \pm 4.5$ & $48.9 \pm 10.1$ & $49.0 \pm 4.8$ & $<0.001$ \\
\hline LA apical diameter (mm) & $47.3 \pm 4.3$ & $48.7 \pm 7.7$ & $50.0 \pm 5.3$ & $<0.001$ \\
\hline LA apical length (mm) & $54.1 \pm 6.3$ & $59.3 \pm 9.9$ & $58.8 \pm 6.9$ & $<0.001$ \\
\hline Pulmonary artery systolic pressure (PASP, $\mathrm{mmHg}$ ) & $42.5 \pm 10.7$ & $45.9 \pm 12.7$ & $48.7 \pm 10.9$ & $<0.001$ \\
\hline End-diastolic volume (EDV, ml) & $116.9 \pm 36.9$ & $146.3 \pm 46.8$ & $186.2 \pm 56.4$ & $<0.001$ \\
\hline End-systolic volume (ESV, ml) & $44.5 \pm 19.1$ & $77.1 \pm 28.7$ & $127.7 \pm 53.2$ & $<0.01$ \\
\hline End-diastolic diameter (EDD, mm) & $49.2 \pm 5.6$ & $54.3 \pm 8.3$ & $60.8 \pm 9.9$ & $<0.02$ \\
\hline End-systolic diameter (ESD, mm) & $31.5 \pm 4.7$ & $39.0 \pm 6.9$ & $47.9 \pm 11.9$ & $<0.001$ \\
\hline Right ventricle (RV, $\mathrm{mm}$ ) & $28.4 \pm 5.6$ & $32.7 \pm 5.4$ & $32.3 \pm 5.8$ & 0.356 \\
\hline
\end{tabular}

EF - ejection fraction; HFmrEF - heart failure with mid-range ejection fraction; HFpEF - heart failure with preserved ejection fraction; HFrEF - heart failure with reduced ejection fraction; LA - left atrium; SD - standard deviation.

\section{Results}

The number of patients in different subgroups was as follows: 609 patients $(68.8 \%)$ had HFpEF, $145(16.3 \%)$ HFmrEF, and 136 patients (15.3\%) had HFrEF. The comparison of the clinical characteristics between these three HF groups is shown in Table 1. The mean age of patients was similar in HFpEF (67.3 \pm 11.3 years), HFmrEF (68.2 \pm 11.7 years) and HFrEF (68.6 \pm 10.6 years). The proportion of females was higher among HFpEF population $(56.0 \%)$, as compared to HFmrEF (39.3\%) and HFrEF (40.4\%).

Examination of the distribution of HF etiology showed that patients with HFpEF exhibited significantly higher rate of arterial hypertension (96.2\%, $p<0.01$ ), while HFmrEF and HFrEF patients had rather higher rate of diabetes mellitus type $2(p<0.05)$. Interestingly, the prevalence of atrial fibrillation (AF) was found to be significantly higher in patients with HFmrEF than in those with HFpEF or HFrEF $(p<0.001)$. In HFrEF group the rates of coronary artery disease and peripheral artery disease (PAD) were significantly higher than in HFmrEF and HFpEF groups (for CAD: $59.6 \%$ vs. $52.4 \%$ and $42.1 \%, p<$ 0.001 ; for PAD: $18.4 \%$ vs. $11.7 \%$ and $9.19 \%$, respectively, $p<0.05)$

Patients with HFrEF had higher frequency of anemia then those with HFpEF and HFmrEF (41.2\% vs. $36.3 \%$ and $32.4 \%$, accordingly, $p<0.001)$. HFrEF patients had also significantly worse renal function than patients with HFpEF and HFmrEF $(p<0.001)$.

The evaluated echocardiographic characteristics of our patients are presented in Table 2 and the medications at discharge in Table 3. 
Table 3 - Therapy at discharge of the HFpEF, HFmrEF, and HFrEF patients

\begin{tabular}{|l|l|l|l|l|}
\hline & $\begin{array}{l}\text { HFpEF } \\
\mathbf{n}(\%)\end{array}$ & $\begin{array}{l}\text { HFmrEF } \\
\mathbf{n}(\%)\end{array}$ & $\begin{array}{l}\text { HFrEF } \\
\mathbf{n}(\%)\end{array}$ \\
\hline Diuretics & $497(81.6 \%)$ & $126(88.1 \%)$ & $122(89.7 \%)$ \\
\hline Beta-blockers & $424(69.0 \%)$ & $100(70.4 \%)$ & $110(80.9 \%)$ & $<0.001$ \\
\hline ACE inhibitors & $217(35.6 \%)$ & $53(37.1 \%)$ & $51(37.5 \%)$ & 0.215 \\
\hline ARBs & $210(34.5 \%)$ & $34(23.8 \%)$ & $34(25.0 \%)$ & $<0.001$ \\
\hline MRA & $54(8.9 \%)$ & $31(21.7 \%)$ & $51(37.5 \%)$ & $<0.05$ \\
\hline Anticoagulant & $225(66.7 \%)$ & $76(74.5 \%)$ & $61(67.0 \%)$ & $<0.05$ \\
\hline Antiplatelet drug & $259(42.5 \%)$ & $58(40.0 \%)$ & $47(34.6 \%)$ & $<0.05$ \\
\hline Antiarrhythmic therapy & $173(51.3 \%)$ & $27(26.5 \%)$ & $53(58.2 \%)$ & $<0.001$ \\
\hline Rate control therapy & $167(48.7 \%)$ & $75(73.5 \%)$ & $38(41.8 \%)$ \\
\hline
\end{tabular}

ACE - angiotensin-converting enzyme; ARBs - angiotensin II receptor blockers; HFmrEF - heart failure with mid-range ejection fraction; HF$\mathrm{pEF}$ - heart failure with preserved ejection fraction; HFrEF - heart failure with reduced ejection fraction; MRA - mineralocorticoid-receptor antagonists.

Table 4 - Mortality in HFpEF, HFmrEF, and HFrEF groups after adjustment for age, sex, CVD, NYHA class and risk factors

\begin{tabular}{|l|l|l|l|}
\hline All-cause mortality & HR $(95 \% \mathrm{Cl})$ & $\begin{array}{l}\text { Model 1 } \\
\text { HR (95\% Cl) }\end{array}$ & $\begin{array}{l}\text { Model } 2 \\
\text { HR (95\% Cl) }\end{array}$ \\
\hline HFpEF & $1.621(1.352-2.154)$ & $1.591(1.245-2.034)$ & $1.625(1.203-2.225)$ \\
\hline HFmrEF & $2.251(0.092-0.686)$ & $2.061(1.683-2.525)$ & $2.146(0.091-0.666)$ \\
\hline HFrEF & $3.167(2.132-3.522)$ & $2.773(1.595-2.975)$ & $2.841(1.660-3.218)$ \\
\hline Age & & $1.178(0.959-1.446)$ & $1.102(0.891-1.362)$ \\
\hline Female gender & & $1.038(1.027-1.048)$ & $1.032(1.021-1.044)$ \\
\hline Arterial hypertension & & & $1.891(1.218-2.286)$ \\
\hline Diabetes mellitus & & & $1.850(1.067-2.677)$ \\
\hline Coronary artery disease & & $1.458(0.981-1.913)$ \\
\hline Cerebrovascular disease & & & $1.400(0.988-1.811)$ \\
\hline NYHA FC & & & $1.579(1.303-2.106)$ \\
\hline Atrial fibrillation & & & $1.680(1.112-2.122)$ \\
\hline
\end{tabular}

$\mathrm{Cl}$ - confidence interval; HFmrEF - heart failure with mid-range ejection fraction; HFpEF - heart failure with preserved ejection fraction; $\mathrm{HFrEF}$ - heart failure with reduced ejection fraction; HR - hazard ratio; NYHA FC - New York Heart Association Functional Classification.

Over a median follow-up of $5.8 \pm 1.5$ years the mortality rate among HFpEF patients was found to be $34.6 \%$, whereas in HFmrEF group 55.9\% and in HFrEF 61.8\%. The adjusted mortality was significantly higher in both HFrEF and HFmrEF versus HFpEF (for HFrEF: HR 3.67; $95 \% \mathrm{Cl}$ $1.74-5.56 ; p<0.01$ and for HFmrEF: HR 2.96; $95 \% \mathrm{Cl} 1.48-$ 4.76; $p<0.01)$.

After the second year of follow-up the HFrEF patients had a non-significantly reduced survival as compared to those with HFmrEF (HR 1.72; 95\% Cl 1.49-2.48; $p=0.12$ ) (Fig. 1).

In the Cox proportional hazards model, including age and gender, patients with HFpEF and HFmrEF had lower mortality than those with HFrEF (Model 1). When age, gender, history of hypertension and diabetes, ischemic etiology, NYHA class, AF and CVD were included, patients with HFpEF and HFmrEF remained at lower risk of death from any cause compared to those with HFrEF (Table 4, Model 2).

The rehospitalization rate for median period of 1.2 year was $22.3 \%$ for HFpEF, $33.1 \%$ for HFmrEF and $33.7 \%$ for
HFrEF. The patients with HFrEF and HFmrEF had a significantly higher risk of readmissions for decompensated HF in comparison to HFpEF ones (for HFrEF: HR 1.67; $95 \% \mathrm{Cl}$ $1.20-2.35 ; p<0.01$ and for HFmrEF: HR 1.58; $95 \% \mathrm{Cl} 1.12-$ $2.22 ; p<0.01)$. The risk of rehospitalizations was similar for HFrEF and HFmrEF patients (HR 1.03; 95\% Cl: 0.93-1.08; $p$ $=0.65$ ) (Fig. 2).

The composite of mortality/readmission rates during the follow-up period was $46.6 \%$ for HFpEF, $57.2 \%$ for HFmrEF, and $63.2 \%$ for HFrEF patients. The risk of this composite end-point was significantly higher in HFrEF (HR 2.49; 95\% Cl 1.14-1.87; $p<0.01$ ) and HFmrEF (HR 1.57; $95 \% \mathrm{Cl} 1.23-2.00 ; p<0.01$ ) as compared to HFpEF (Fig. 3). The patients with HFmrEF had slightly (non-significantly) lower risk of composite mortality/readmissions than those with HFrEF (HR 0.86; 95\% Cl 0.82-1.04; $p=0.104$ ). The ROC analysis showed a cut-off point of $50 \% \mathrm{EF}$, i.e. LVEF $<50 \%$ was associated with higher mortality and rehospitalization rates among the entire studied HF population (sensitivity $65 \%$, specificity $72 \%$, AUC $0.67, p<0.01$ ). 


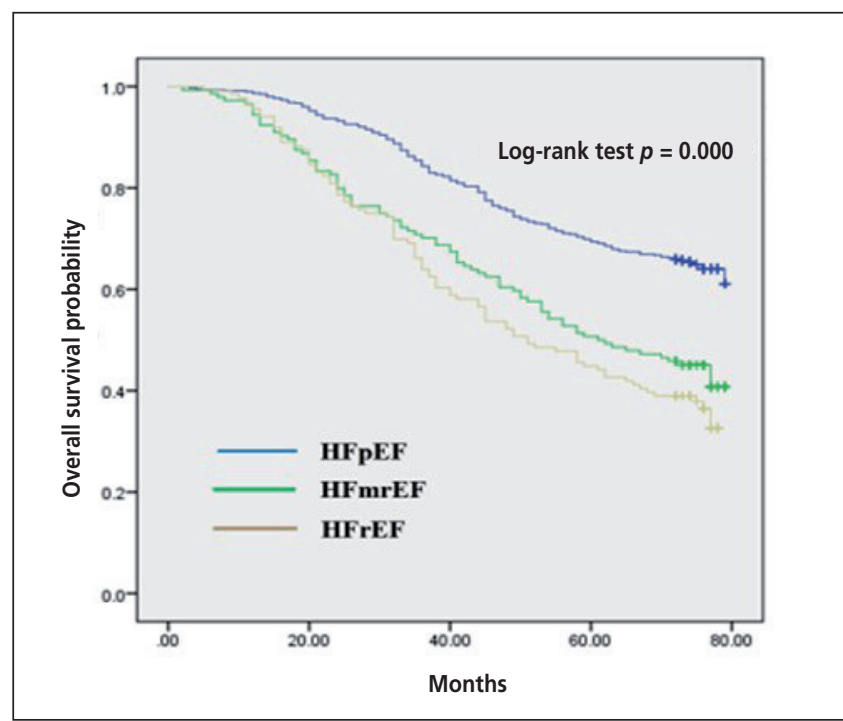

Fig. 1 - Survival of patients with HFpEF, HFmrEF, and HFrEF. HFmrEF - heart failure with mid-range ejection fraction; HFpEF - heart failure with preserved ejection fraction; HFrEF - heart failure with reduced ejection fraction.

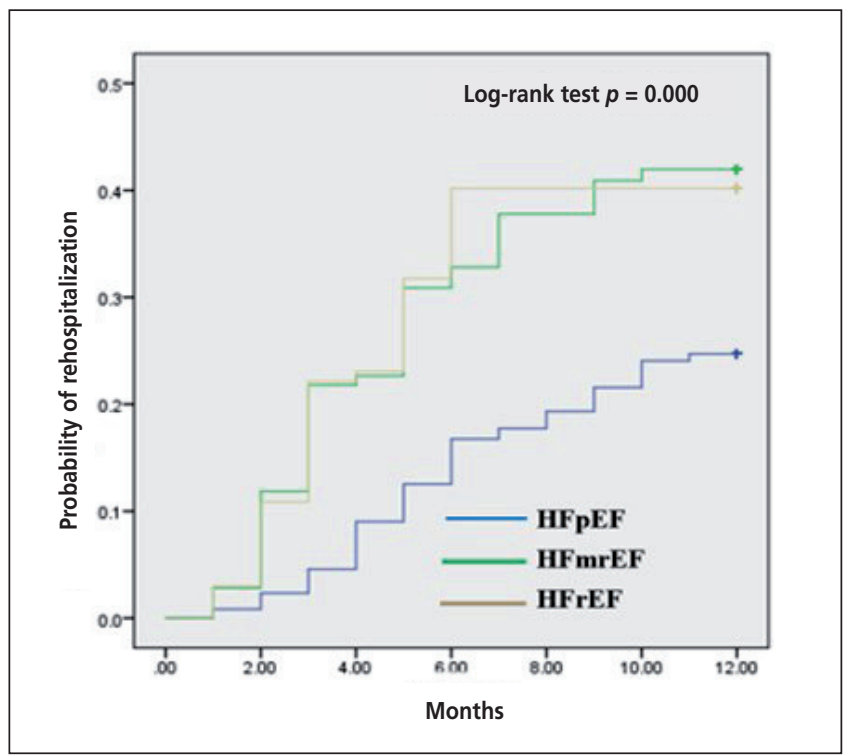

Fig. 2 - The risk of rehospitalizations in patients with HFpEF, HFmrEF, and HFrEF.

HFmrEF - heart failure with mid-range ejection fraction; HFpEF heart failure with preserved ejection fraction; HFrEF - heart failure with reduced ejection fraction.

\section{Discussion}

This is the first study in Bulgaria which investigated the etiology, risk factors, clinical and echocardiographic characteristics, and prognosis of altogether 890 patients with HFpEF, HFmrEF, and HFrEF. The obtained data showed the prognosis of HF patients was primarily linked to the differences in LVEF. This is the main reason for dramatic decrease of incidence of acute myocardial infarction during the last ten years.

The data from registries and epidemiological studies indicate that up to $50 \%$ of patients with heart failure

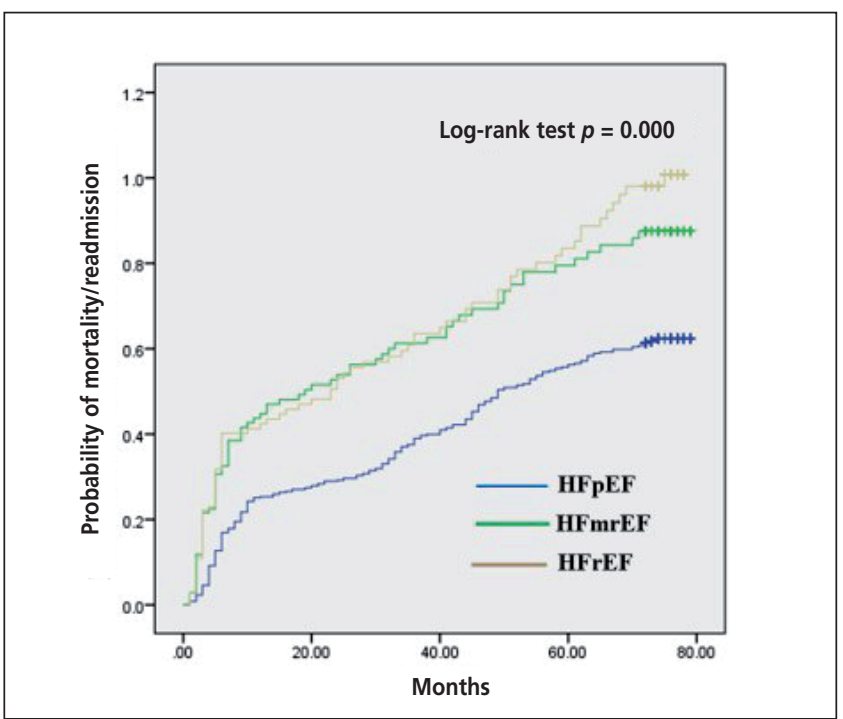

Fig. 3 - The risk of composite mortality/readmissions in patients with HFpEF, HFmrEF, and HFrEF. HFmrEF - heart failure with mid-range ejection fraction; HFpEF - heart failure with preserved ejection fraction; HFrEF - heart failure with reduced ejection fraction.

have a preserved ejection fraction, and this proportion has increased over the time. The prompt and effective treatment of ACS patients, coupled with a lack of evidence-based effective treatments for HFpEF, is resulting in an emerging epidemic of HFpEF and lower number of patients left ventricular systolic dysfunction. The prevalence of HFpEF is increasing over the time, and a population burden of aging and comorbidities predicts even higher rates of HFpEF in the coming decades. This is the reason for higher proportion of patients with HFpEF in our center.

In our study the HFpEF patients were more often females and more frequently had arterial hypertension compared to those with HFmrEF and HFrEF, while most of the clinical characteristics of HFmrEF patients were similar to HFrEF ones. Baseline co-morbidities such as diabetes mellitus type 2 and atrial fibrillation were more frequent in HFmrEF and HFrEF groups in comparison to HFpEF. Importantly, CAD and PAD were presented more frequently in HFrEF patients and the renal function was worse in this group as well.

The all-cause mortality after approximately 5.8 years of follow-up was lowest among HFpEF patients. It should be pointed out the mortality rate in our HFrEF group began to increase as compared to HFmrEF, after the second year of follow-up, but the difference was not significant. Similarly, the readmissions rate after 1.2 year of follow-up was markedly lower in HFpEF patients and similar in those with HFmrEF and HFrEF. The rehospitalization rates of our HFpEF and HFrEF patients were close to those in ESC-HF-LT Registry, ${ }^{30}$ but higher in our HFmrEF patients $(33.1 \%$ vs. $22.0 \%)$, probably because they often remain untreated or insufficiently treated in outpatient (ambulatory) settings. The incidence of the composite end-point of rehospitalizations and mortality was significantly lower in our patients with HFpEF in comparison to those with HFmrEF and HFrEF. The same results were shown in ESC-HF-LT Registry. ${ }^{30}$ 
Actually, in the literature the data about mortality rates for HFpEF varied from $22 \%$ to $65 \% .31,32$ The published mortality rates in HFpEF and HFrEF patients were markedly influenced by the type of the study from which the data had been taken and by the heterogeneity of the study population. The survival rate in MAGGIC meta-analysis (adjusted for age, gender, etiology, and history of hypertension, diabetes, and atrial fibrillation) $)^{15}$ was $~ 32 \%$ higher in HFpEF than in HFrEF, whereas epidemiological studies presented similar outcomes in both groups. ${ }^{31,33}$ It is important to note that the mortality difference between HFpEF and HFrEF has been decreased in the very elderly. In other meta-analysis with 24501 patients from 17 studies, Somaratne et al. demonstrated that HFpEF patients had half the odds of death compared with patients with HFrEF. ${ }^{34}$ Gottdiener et al. found 6-year mortality for HFpEF $43 \%$ and $54 \%$ for HFrEF. ${ }^{35}$ Probably, this relatively high mortality rate in HFpEF was due to the higher proportion of elderly patients and the advanced stage of HF.

We paid special attention on HFmrEF patients because of the insufficient data in the literature concerning their prognosis. The data in CHARM study showed that patients with LVEF over $45 \%$ had a much lower risk of adverse cardiovascular outcomes than those with reduced systolic function, with HR 1.31 for every 10\% reduction of LVEF below $45 \% .{ }^{36}$ In our study the ROC-analysis revealed a cut-off point of $50 \% \mathrm{EF}$ : values < 50\% EF were associated with higher mortality and rehospitalization rates among all studied HF patients (AUC 0.67; sensitivity $65 \%$; specificity $72 \%, p<0.01$ ). In OPTIMIZE-HF and ADHERE registries the mortality rates in HFpEF and HFmrEF patients were similar and lower than in HFrEF patients. ${ }^{37,38}$ GWTG-HF registry showed in HFmrEF population a mortality percentage between these ones in HFpEF and HFrEF, but closer to HFpEF. ${ }^{39}$

Overall, the epidemiological findings demonstrated that the HFmrEF category occupied an intermediate position between the two established categories (HFpEF and HFrEF) concerning clinical profile and burden of comorbidities. In our study, the extent of left/right ventricular and atrial enlargement, pulmonary hypertension and valve abnormalities in HFmrEF patients were midway between HFpEF patients and those with HFrEF, which was in accordance with previous observations. However, our HFpEF patients had better prognosis during 5.8-year follow-up period than the other two HF groups. In this context, HFmrEF may represent an early stage of HFrEF and HFmrEF patients may have benefit from the same therapeutic strategies, approved and used in patients with HFrEF. This suggestion could be supported by the data of Tsutsui et al. who concluded that HFmrEF showed a transitional status between HFpEF and HFrEF rather than an independent entity. ${ }^{40}$ Moreover; in our study the frequency of prescription of guideline-recommended medications for HFrEF patients (ACEI/ARBs, beta-blockers, and MRAs) was not as high as expected. Thus, improvement in the management of our HFrEF and HFmrEF patients is urgently needed.

\section{Limitations}

It must be acknowledged that this study has some important limitations. First, we enrolled patients from a single center in Sofia; therefore, our results may not be extended to other populations with different ethnicity and/or from other geographical areas. Second, we did not have serial data about the EF in our study, so we cannot determine if there are patients with HFmrEF and HFpEF that were previously with HFrEF, and these patients with improved EF may have different outcomes. Likewise, we do not have data on whether some patients were previously HFmrEF or HFpEF, who subsequently had reduction in EF. Third, postdischarge data were not directly tracked or recorded. In addition, because we did not investigate cardiovascular-specific mortality, we were not able to comment on potential differences between HF groups for this end-point. Cause-specific readmissions were based on diagnostic-related group codes and could be a subject to misclassification.

\section{Conclusion}

Our data showed that patients with HFpEF had better prognosis than those with HFmrEF and HFrEF. However, the mortality and rehospitalization rates were similar in HF patients with EF below $50 \%$. This means that HFmrEF may represent an early stage of HFrEF and HFmrEF patients may have benefit from the same therapeutic strategies used for patients with HFrEF.

\section{Conflicts of interest}

The authors declare no conflict of interest.

\section{Funding}

This research received no external funding.

\section{References}

1. Ponikowski P, Voors AA, Anker SD, et al. 2016 ESC guidelines for the diagnosis and treatment of acute and chronic heart failure: the Task Force for the diagnosis and treatment of acute and chronic heart failure of the European Society of Cardiology (ESC) developed with the special contribution of the Heart Failure Association (HFA) of the ESC. Eur Heart J 2016;37:2129-2200.

2. Runev N, Manov E. Diastolic left ventricular function - invasive assessment. Lambert Academic Publishing, 2014.

3. Naydenov S, Donova T, Runev N, Manov E. Atrial fibrillation and heart failure: clinical and instrumental analysis. Bulg Cardiol 2012;18(Suppl. 2):16.

4. Tasheva R, Grigorov MI, Runev N, Vitlianova K. Clinical utility of NT-proBNP for assessment of the left ventricular end-diastolic pressure in chronic heart failure patients with preserved ejection fraction. Bulg Cardiol 2015;3:33-38.

5. Naydenov S, Runev N, Manov E, et al. Risk Factors, Co-Morbidities and Treatment of In-Hospital Patients with Atrial Fibrillation in Bulgaria. Medicina (Kaunas) 2018;54(3):34.

6. Pancheva R, Runev N, Manov E, et al. A gradient of frequency of rehospitalization of heart failure patients between different types of atrial fibrillation and correlation with left atrial diameter. Eur J Heart Fail 2018;20(Suppl. S1):243.

7. Runev N, Manov E, Naydenov S, Donova T. Prevalence of the cardiovascular risk factors in Bulgarian female population. Eur J Prev Cardiol 2015;22(Suppl. 1):S103.

8. Pfeffer MA, Shah AM, Borlaug BA. Heart failure with preserved ejection fraction in perspective. Circ Res 2019;124:1598-1617.

9. Dunlay SM, Roger VL, Redfield MM. Epidemiology of heart failure with preserved ejection fraction. Nat Rev Cardiol 2017; 14:591-602. 
10. Shah SJ, Kitzman DW, Borlaug BA, et al. Phenotype-specific treatment of heart failure with preserved ejection fraction: a multiorgan roadmap. Circulation 2016;134:73-90.

11. Pancheva R, Runev N, Manov E, et al. Predictors of mid-term rehospitalization and mortality rates in Bulgarian patients with heart failure and preserved ejection fraction: a single-center study. Eur J Heart Fail 2018;20(Suppl. S1):573.

12. Pancheva $R$, Runev N, Manov E, et al. Which patients with heart failure and preserved ejection fraction in Bulgaria are more likely to be rehospitalized and have higher mortality rate? Acta Medica Mediterr 2019;35:2575-2582.

13. Andersson C, Vasan R. Epidemiology of heart failure with preserved ejection fraction. Heart Fail Clin 2014;10:377-388.

14. Fonarow GC, Stough WG, Abraham WT, et al. Characteristics, treatments, and outcomes of patients with preserved systolic function hospitalized for heart failure: a report from the OPTIMIZE-HF Registry. J Am Coll Cardiol 2007;50:768-777.

15. Meta-analysis Global Group in Chronic Heart Failure. The survival of patients with heart failure with preserved or reduced left ventricular ejection fraction: an individual patient data meta-analysis. Eur Heart J 2012;33:1750-1757.

16. Lenzen MJ, Scholte op Reimer WJ, Boersma E, et al. Differences between patients with a preserved and a depressed left ventricular function: a report from the EuroHeart Failure Survey. Eur Heart J 2004;25:1214-1220.

17. Steinberg BA, Zhao $X$, Heidenreich PA, et al. Trends in patients hospitalized with heart failure and preserved left ventricular ejection fraction: prevalence, therapies, and outcomes. Circulation 2012;126:65-75.

18. Pancheva R, Runev N, Manov E, et al. Predictors of mid-term rehospitalization and mortality rates in Bulgarian patients with heart failure and mid-range ejection fraction: a single-center study. Eur J Heart Fail 2018;20(Suppl. S1):59.

19. Pancheva R, Runev N, Manov E, et al. The rehospitalization rates among patients with preserved, mid-range and reduced ejection fraction: databased analysis. Eur J Heart Fail 2018;20(Suppl. S1):241.

20. Lauritsen J, Gustafsson F, Abdulla J. Characteristics and long-term prognosis of patients with heart failure and mid-range ejection fraction compared with reduced and preserved ejection fraction: a systematic review and meta-analysis. ESC Heart Fail 2018;5:685-694.

21. Lofman I, Szummer K, Dahlstrom U, et al. Associations with and prognostic impact of chronic kidney disease in heart failure with preserved, mid-range, and reduced ejection fraction. Eur J Heart Fail 2017;19:1606-1614.

22. Coles $\mathrm{AH}$, Tisminetzky M, Yarzebski J, et al. Magnitude of and prognostic factors associated with 1-year mortality after hospital discharge for acute decompensated heart failure based on ejection fraction findings. J Am Heart Assoc 2015;4:e002303.

23. Gomez-Otero I, Ferrero-Gregori A, Varela Roman A, et al. Mid-range ejection fraction does not permit risk stratification among patients hospitalized for heart failure. Rev Esp Cardiol 2017;70:338-346.

24. Pascual-Figal DA, Ferrero-Gregori A, Gomez-Otero I, et al. Mid-range left ventricular ejection fraction: clinical profile and cause of death in ambulatory patients with chronic heart failure. Int J Cardiol 2017;240:265-270.

25. Rickenbacher P, Kaufmann BA, Maeder MT, et al. Heart failure with mid-range ejection fraction: a distinct clinical entity?
Insights from the Trial of Intensified versus standard Medical therapy in Elderly patients with Congestive Heart Failure (TIME-CHF). Eur J Heart Fail 2017;19:1586-1596.

26. Koh AS, Tay WT, Teng THK, et al. A comprehensive populationbased characterization of heart failure with mid-range ejection fraction. Eur J Heart Fail 2017;19:1624-1634.

27. Williams B, Mancia G, Spiering W, et al. 2018 ESC/ESH Guidelines for the management of arterial hypertension: The Task Force for the management of arterial hypertension of the European Society of Cardiology (ESC) and the European Society of Hypertension (ESH). Eur Heart J 2018;39:3021-3104.

28. Baumgartner H, Falk V, Bax JJ, et al. 2017 ESC/EACTS Guidelines for the management of valvular heart disease. Eur Heart J 2017;38:2739-2791.

29. Inker LA, Astor BC, Fox CH, et al. KDOQI US Commentary on the 2012 KDIGO Clinical Practice Guideline for the Evaluation and Management of CKD. Am J Kidney Dis 2014;63:713-735.

30. Crespo-Leiro MG, Anker SD, Maggioni AP, et al. European Society of Cardiology Heart Failure Long-Term Registry (ESC-HF-LT): 1-year follow-up outcomes and differences across regions. Eur J Heart Fail 2016;18:613-625.

31. Owan TE, Hodge DO, Herges RM, et al. Trends in prevalence and outcome of heart failure with preserved ejection fraction. N Engl J Med 2006;355:251-259.

32. Varadarajan P, Pai RG. Prognosis of congestive heart failure in patients with normal versus reduced ejection fractions: results from a cohort of 2,258 hospitalized patients. J Card Fail 2003;9:107-112.

33. Bhatia RS, Tu JV, Lee DS, et al. Outcome of heart failure with preserved ejection fraction in a population-based study. $\mathrm{N}$ Engl J Med 2006;355:260-269.

34. Somaratne JB, Berry C, McMurray JJ, et al. The prognostic significance of heart failure with preserved left ventricular ejection fraction: a literature based meta-analysis. Eur J Heart Fail 2009;11:855-862.

35. Gottdiener JS, McClelland RL, Marshall R, et al. Outcome of congestive heart failure in elderly persons: influence of left ventricular systolic function. The Cardiovascular Health Study. Ann Intern Med 2002;137:631-639.

36. O'Meara E, Clayton T, McEntegart MB, et al. Clinical correlates and consequences of anemia in a broad spectrum of patients with heart failure: results of the Candesartan in Heart Failure: Assessment of Reduction in Mortality and Morbidity (CHARM) Program. Circulation 2006;113:986-994.

37. Fonarow GC, Stough WG, Abraham WT, et al. Characteristics, treatments, and outcomes of patients with preserved systolic function hospitalized for heart failure: a report from the OPTIMIZE-HF Registry. J Am Coll Cardiol 2007;50:768-777.

38. Sweitzer NK, Lopatin M, Yancy CW, et al. Comparison of clinical features and outcomes of patients hospitalized with heart failure and normal ejection fraction $(\geq 55 \%)$ versus those with mildly reduced ( $40 \%$ to $55 \%$ ) and moderately to severely reduced (<40\%) fractions. Am J Cardiol 2008;101:1151-1156.

39. Cheng RK, Cox M, Neely ML, et al. Outcomes in patients with heart failure with preserved, borderline, and reduced ejection fraction in the Medicare population. Am Heart J 2014;168:721730.

40. Tsutsui H, Tsuchihashi-Makaya M, Kinugawa S. Clinical characteristics and outcomes of heart failure with preserved ejection fraction: Lessons from epidemiological studies. J Cardiol 2010;55:13-22. 